\title{
Coleridge and the National Debt
}

Paul R. Stephens

\begin{abstract}
Samuel Taylor Coleridge's reflections on the British national debt recur throughout his work. This article examines his understanding of the economic function of the debt, and contends that his arguments are conditioned by the ideas of moral duty and the social contract derived from Immanuel Kant. The poet's economics are consequently shown to relate to the ethics of the private debtor-creditor relationship developed in his moral and theological thought. This establishes Coleridge as a forerunner to recent scholarship on the ethics of economic indebtedness, and suggests further avenues for the exploration of debt in the Romantic period and beyond.
\end{abstract}

KEYWORDS: Coleridge; Kant; Lay Sermons; The Friend; national debt; taxation; ethics

The reputation that Samuel Taylor Coleridge acquired as the sage of Highgate had little to do with his economic thought. Nonetheless, during his long period of residence with the physician James Gillman, the poet's visitors heard numerous economic ideas weaved into a rich tapestry of topics. A selection of Coleridge's monologues was published posthumously by his nephew Henry Nelson Coleridge in Table Talk (1835). An entry dated 31 March 1833 opens with the poet's long-held views on the national debt:

What evil results to this country from the National Debt? ... There may, certainly, be particular local evils and grievances resulting from the mode of taxation or collection; but how can that debt be in any proper sense a burthen to the Nation, which the Nation owes to itself [?] ... It is really and truly nothing more than so much money ... raised annually by the State for the purposes of quickening industry. (Coleridge, 1990, 1: $350-1)$

Not everyone was impressed with this analysis. The playwright Henry Taylor (1888: 39-40) reports in a letter to Robert Southey the details of a recent trip to visit Coleridge alongside the young John Stuart Mill. Having listened to the poet muse 'upon such subjects as the National Debt', Mill comments on their walk home that economics was principally concerned with 'matters of calculation' on which one 'must be quite right or quite wrong'. This distinguished the field from reflections on 'the moral and political relations of society', upon which one may also be quite wrong, yet nonetheless 'instructive'. Mill would hone these ideas in his essay 'Coleridge' (1985: 155), where he defends the poet's normative social thought but asserts that '[in] political economy especially he writes like an arrant driveller'.

Coleridge's reflections on Britain's national debt appear throughout his published prose, notebooks, and letters. The most detailed examinations occur in an essay from his periodical The Friend (Friend) entitled 'On the Vulgar Errors Respecting Taxes and Taxation' ('Taxes', 1809), and in his second Lay Sermon (Sermon, 1817) (Coleridge, 1969, 1: $228-44 ; 1972: 115-230)$. In broad terms, 'Taxes' attempts to refute the view that taxation 
immiserates Britain's labouring class, while Sermon examines the commercial spirit informing the economic phenomena of the nation's post-Waterloo recession. William F. Kennedy (1958: 26) argues that each essay's conception of public finance offers a protoKeynesian defence of deficit spending during economic downturn. This interpretation encouraged subsequent critics to reassess the poet's economics as 'sufficiently original' and 'surprisingly modern' (Colmer, 1959: 142; Calleo, 1966: 14). More recent studies contextualise Coleridge's analysis of public credit in relation to his cultural and theological thought, examining how he viewed the debt as fuelling 'the nation's commercial and epistemic energies' to help foster a 'symbolic consciousness of national unity' (Connell, 2001: 153; Dick, 2013: 93). This scholarship persuasively counters Mill's condescension, but remains largely focused on the social function of the debt within the national economy.

The following article takes a different approach by examining Coleridge's socioeconomic conception of the national debt in relation to the moral concepts of debt, duty, and obligation. The financial and ethical significances of these words have been interrelated in English since the thirteenth century. ${ }^{1}$ These etymological links have been recently reexamined by scholars exploring the ethics of economic indebtedness. Some take as their point of departure Karl Marx's view that 'Credit is the economic judgement on the morality of a man' (1992: 264). They develop incisive examinations of how 'paying one's debts is not the essence of morality', and how the 'debt economy combines "work on the self" and [labour] ... such that "ethics" and economics function conjointly' (Graeber, 2011: 390; Lazzarato, 2012: 10-11). Although operating in distinct conceptual registers, such scholarship responds to growing concerns over the negative externalities of deregulated finance within Europe and across the global economy. These concerns are often discussed in relation to a tension between the public and private spheres. This can be seen today in debates over policy responses to sovereign debt crises and debt-encumbered consumers; in defences of national austerity programmes that employ the symbol of the private household; and in the citation of GDP growth statistics to conflate national wealth and individual wellbeing.

Coleridge's essays presciently resonate with these twenty-first century debates, despite their focus on the conditions of early-nineteenth century industrial capitalism. The present article therefore seeks to establish Coleridge as a forerunner of recent studies on the ethics of economic indebtedness. The main challenge to this proposal, however, is offered by the poet's assent to the distinction between the duties of the public and private spheres. This forms a central proposition of his political philosophy in Friend, where he argues that those 'who cannot perceive the moral differences of national and individual duties, comprehends neither' $(1969,1: 271-2)$. One recent attempt to reconfigure this duality is offered by Alexander X. Douglas (2015: 153), who distinguishes 'usurious' from 'abusurious' debt. Usurious debt results from 'productive' lending, such as government investment in healthcare provision. Abusurious debt, on the other hand, results from 'extractive' lending, such as predatory bank lending to impoverished debtors, and which therefore diminishes the moral duty of the debtor to settle the debt (153). The present article draws upon Douglas's distinction to argue that Coleridge's conception of public debt remains conditioned by his reflections on private indebtedness and moral duty. To this end, I will first examine the economic role of public debt in 'Taxes' and Sermon, suggesting how Coleridge frames these ideas within the terms of his moral philosophy. In the second half of the article, I develop this 
analysis in relation to the ethics of the private debtor-creditor relationship, contrasting the significance of this relationship in Coleridge's Aids to Reflection (Reflection, 1825), William Paley's The Principles of Moral and Political Philosophy (Principles, 1785), and Immanuel Kant's idea of duty and the social contract. The article aims to prepare the ground for more detailed contributions to Romanticist debt studies, but also to encourage broader questions concerning the debates around debt and taxation, and their relationship to the language of moral thought.

\section{I: The unifying national debt}

Britain's national debt has been a matter of controversy since its foundation in the late seventeenth century. After the Glorious Revolution in 1688, William III embarked upon the Nine Years War against France. Instead of funding his war through taxation, he established what would become the national debt by selling government bonds to affluent merchants and traders, who coalesced in 1694 to form the private Bank of England (BoE). Successive governments continued to create public debt to fund wars throughout the eighteenth century. Between the end of the Seven Years War (1763) and the start of the Revolutionary wars (1792), Britain's debt increased in nominal terms from $£ 100$ million to $£ 240$ million, and from 100\% to $150 \%$ in relation to its debt-to-GDP ratio (Dome, 2004: 6; Mitchell, 1988: 6002). To service the unfunded portion of this debt, and to facilitate the expansion of credit, successive governments increased the volume of fiat currency in excess of the nominal value of the BoE's bullion reserves. By 1797 - due to fears that the spectre of French invasion would cause bank runs - the Pitt government's Bank Restriction Act forced the BoE to suspend conversion of paper currency for gold. The journey towards financial capitalism had begun.

The issue of spiralling national debt during the long eighteenth century became a central theme within the emerging discipline of political economy. Until 1792, criticism of the debt emerged chiefly from a Tory-Country perspective, while supporters were aligned with commercial and even revolutionary interests (Winch, 1996: 9). These views are developed respectively by David Hume and Thomas Paine. In 'Of Public Credit' (1752), Hume (2008: 203) argues that public revenue is a 'mortgage' on future generations who are 'obliged' to service the debt; a pernicious situation where '[the] public is a debtor, whom no man can oblige to pay' (215). Although praising government investment for multiplying productive capital (205), the essay sees the corresponding increase in 'idle' stockholders as necessitating a long-term rise in wages and taxation on consumer goods (207). The result, for Hume, is that 'the nation must destroy public credit, or public credit will destroy the nation' (212). Although Paine in Rights of Man: Part the Second (1792) concurs with Hume insofar as he sees the debt as '[keeping] alive a capital, useful to commerce' (2008: 286), the tract argues that '[the] burthen of the national debt consists not in its being so many millions ... but in the quantity of taxes collected every year to pay the interest' (313-4). Paine's support of public credit is therefore conditional on the replacement of regressive taxation with a progressive system that alleviates the relative tax burdens on the labouring class. The assessment of public debt by each author, then, is premised on the extent to which they consider abusurious debts an ineradicable aspect of the financial system. 
Coleridge's defence of the national debt in 'Taxes' is formulated in direct response to the arguments of Hume and Paine. The essay consequently echoes the newfound Tory support for Britain's financial system that blossomed during the Revolutionary wars (Winch, 1996: 9). However, Coleridge's targeted criticisms show a more nuanced interest in their ideas than those prompted by mere patriotism. To this end, 'Taxes' critiques two aspects of Hume's essay. His first criticism takes aim at the fact that Hume considered 'a debt of a nation' to be 'the same as the debt of an individual', a supposed 'self-evident axiom' that rendered the nation's 'ruin arithmetically demonstrable' (Coleridge, 1969, 1: 234). This is a fair summary of Hume's suggestion that identical 'maxims of conduct' may apply to 'the public and an individual' (Hume, 2008: 204). The second criticism asserts that 'Hume went on the false assumption' that 'only [a part] of the Nation was interested in the preservation of the Public Credit' (Coleridge, 1969, 1: 236), a response to Hume's view that the debt is disproportionately beneficial to merchants and stockholders. Coleridge counters these arguments by first refuting the idea that 'a nation in debt' has any equivalence to an 'individual tradesman' facing 'bankruptcy' (228-9). He further observes that the growth of the debt has facilitated the expansion of commercial activity to the benefit of all social classes. This ranges from the capital requirement for public infrastructure projects beyond the resources of private investment ('Roads, Rivers, and Canals') to the increasing opportunities for individual 'enjoyments' (233-4). Even warfare aids the economy by stimulating domestic production, thereby saving the hardworking 'gunsmiths' and 'gunpowder-makers' from starvation (243). Although military expenditure may cause the 'stagnation' of certain industries by monopolising available capital, the effects are indistinguishable from 'commercial regulations' during times of peace (230). Abusurious debts appear to play no part in this vision.

In his response to Paine, Coleridge censures his ideas relating to regressive taxation. 'Taxes' opens with a fair summary of Paine's view that tax is chiefly necessitated because of the 'wars and state-corruption' of 'monarchy and aristocracy', and that without these encumbrances the nation might afford to support the poor (Coleridge, 1969, 1: 228). Coleridge counters that taxes are only 'injurious' to the nation through imperfect application, and that their impact must be assessed 'not by the amount ... taken from each individual, but by that which remains behind' (229-30). If net incomes increase over time, Coleridge implies, the material conditions of the poor will improve in real terms irrespective of any tax increases. A range of organic metaphors are marshalled to convey the hierarchical social cohesion fostered through the circulations of capital and taxation, such as the 'symbol' of the water cycle that precipitates upon the fecund 'corn-field' and 'unprofitable sand-waste' alike (230). This vision of a harmonious financial system is contrasted with the disunity of postRevolutionary France, whose 'unprincipled Government' and 'taxable Classes' are seen as 'two Individuals' lacking all 'communion of Interests' (236). Paine's revolutionary sympathies, it is implied, reject the 'unwritten code of ... common interest' that characterise Britain's own 'individual efforts working together' (232). Britain's usurious and productive debt, then, is contrasted with the abusurious system of France in terms of the relationship between economic and ethical ideas.

I contend that Coleridge's refutations of Hume and Paine in 'Taxes' seek to correct a duality in their work between ethical unity and economic division. This duality consists in the 
relationship between, on the one hand, ethical axioms that consider public and private indebtedness as identical, and on the other hand, the economic division of competing class interests within the nation state. Coleridge's defence of Britain's financial system retains this duality but reverses its terms to emphasise instead economic unity and ethical division. His duality consequently seeks to explicate the socio-economic unity fostered by the financial system, while maintaining the ethical distinction between public and private indebtedness. To some extent this mode of analysis articulates the 'double-minded' nature of Coleridge's broader thought, which is 'principally divided between the rival attractions of unity and division' (Perry, 1999: 4). In 'Taxes', the national debt becomes the central symbol of the economy, whose purpose is to embody and unify the rival attractions of the ethico-economic duality. In this manner, Coleridge $(1969,1: 233)$ asserts with anaphoral verve that

it is the national debt which has wedded in indissoluble union all the interests of the state, the landed with the commercial, and the man of independent fortune with the stirring tradesman and reposing annuitant. It is the National Debt, which ... has made it impossible for ... [most] men to retain their own former comforts without joining in the common industry.

The shared prosperity that results from the union of public and private interests embodied in the debt is directly linked to the question of public and private morality. On the one hand, the debt and corresponding 'system of credit' is seen to 'cement' the 'materials' of the British state, from 'the sovereignty of law' and 'our religious sects', to 'the purity, or at least the decorum of private morals' (232-3). This fusion forms the core of Coleridge's mature political philosophy as set out in On the Constitution of the Church and State (Church, 1830), a work that develops 'the Idea of the State' where distinct economic classes form a coherent 'moral unit' (Coleridge, 1976: 107-8). On the other hand, however, 'Taxes' sees the debt's unification of interests as operating through a 'principle of attraction and repulsion' (Coleridge, 1969, 1: 231). This oppositional principle is seen to explain how the 'distinct character[s]' of nations were nonetheless 'drawing together into one system' through the processes of global trade (231). Yet this same principle must also be seen to explain how the moral unity of the state subsumes the duties of private morality, which, Coleridge insists, remain distinct (271-2, quoted above). The moral unity of economic interests embodied in the debt therefore embodies in itself the imperfect division between public and private morality. And because 'Taxes' perceives the debt as usuriously productive, the issue of abusurious debt is consequently consigned to the sphere of private morality alone.

\section{II: The idea of the national debt}

One purpose of 'Taxes' is to defend the fruits of public credit from critics who saw Britain's financial system as rife with abusurious debts. Coleridge $(1969,1: 234)$ offers a distinct conception of ethical duty to achieve this aim, arguing that the national debt 'has added to our public duties the same feeling of necessity' experienced by 'family [members] in their [mutual] conduct'. This suggestion - that support for public credit is a public duty akin to our private familial duties - is developed at greater length in Sermon. The essay's epigraph - 
'Blessed are ye that sow beside all waters' (Isaiah xxxii 20) - is described as constituting 'a Command in the form of a Promise' that 'instructs us in our duty and forecloses every possible objection to its performance' (Coleridge, 1972: 139-40). These extracts together distil the relationship between the ethical categories of debt, duty, and obligation that underpin Sermon's explanation of Britain's post-Waterloo recession.

The economic analysis in Sermon is rooted in a set of Kantian concepts that Coleridge develops throughout his mature moral and political philosophy: the epistemological faculties of Sense, Reason, and Understanding. Sermon draws upon these concepts while offering no clear explanation of their meaning. What is crucial to comprehend the essay's economics, however, is the way in which the three faculties inform the three theories on the 'Origin of Government' that Coleridge had previously outlined in Friend (1969, 1: 166). In simple terms, the first theory sees humans as animals subject to 'passive sensation' which 'denies all truth ... to the words, RIGHT and DUTY' (166). A second theory derives from Jean-Jacques Rousseau, and sees our moral 'duties of obedience' to government as springing 'exclusively from principles of pure Reason' (205-6), but whose unique source in reason fosters the form of reckless political rationalism exemplified by 'Paine's Rights of Man' (178, my italics). A third theory sees man as 'gifted with understanding', the prudential 'faculty of suiting measures to circumstances' that 'experience has proved to be expedient' (176-7). ${ }^{2}$ Coleridge's political philosophy is informed by his adherence to this third theory, in which the faculty of prudential understanding marshals the knowledge provided by sense and reason to produce a richer comprehension of economic phenomena and moral duty.

Coleridge's three theories of government underpin Sermon's explanation of the duties and obligations that the British citizen incurs towards the nation's financial system. These duties were not apparent to all of Coleridge's contemporaries. Sermon opens with a lengthy censure of the 'political empirics' who proffer erroneous causes for the post-war recession (Coleridge, 1972: 143). The sense-based irrationality of populist demagogues such as William Cobbett is castigated for its 'unsophisticated understandings' of the financial system (155). This generates ideas which are 'true only under particular conditions', but which excite the 'animal enthusiasm' of their intended labouring class audiences (153). The alignment of demagogy with disunity distinguishes their opinions from those principles binding 'the citizen to his country, the spirit to its Creator' (151), and separates them from the unity of interests embodied in the 'expanding warmth of public credit' (168). Demagogic thought is flawed because its sensual comprehension of economic phenomena precludes all understanding of moral duty.

Overcoming the perceived limitations of demagogy requires the application of the prudential understanding. This brings Coleridge to the central hypothesis of Sermon: that 'preparing [the] country for a change in its external relations' requires 'a corresponding change in the mind of the nation' (1972: 191-2). He therefore encourages the reader to develop an understanding of Britain's financial system in Kantian terms:

The corruptions of a system can be duly appreciated by those only who have contemplated the system in that ideal state of perfection exhibited by the reason; the nearest possible approximation to which ... it is the business of the prudential understanding to realize ... [This allows us] to master the Ideal of a beneficent and 
judicious system of Finance as the preliminary to all profitable insight into the defects of any particular system in actual existence. (156-7)

The passage shows Coleridge's scholastic interest in epistemological and ontological categories in full bloom. However, its basic aim is to encourage the reader to distinguish the particular defects of Britain's post-war economy from the essential beneficence of the nation's system of public credit. Sermon's summary of the economy's defects offers a broadly conventional analysis of economic phenomena. The war is seen to have acted as a 'universal stimulant', generating 'high wages' for artisans, the 'high prices of agricultural produce', and productive investment in national infrastructure (158-9). However, the postwar influx of demobilised militia into the labour market caused downward pressure on wages, a subsequent lack of effective demand ('the great customer at home wants less'), and a downturn commensurate with the 'great fluctuations' of trade, all augmented by the government's retrenchment programme and abolition of income tax (158-61). These phenomena are collectively exacerbated by the developing 'blind practices' of 'speculation in the commercial world' (161), where 'Revolutions of Credit' are enflamed by the 'vaporous exaltation' of the 'Gaming Table', but which periodically crash and cause 'serious injury to the Moral Sense' (203-7).

The central problem raised by Sermon's analysis of the post-war economy is the extent to which structural economic phenomena relates to the private moral sense. But what precisely is the moral sense? At one point Coleridge (1972: 161) suggests that the personal 'improvidence' of financial traders and the 'sensual vices' of affluent farmers are both cause and effect of the externalities of credit and trade. But simply blaming the private individual or identifiable groups of individuals remains for him unsatisfactory. The remainder of Sermon therefore examines the kernel of these assertions. This takes the form of an effort to diagnose the 'ultimate causes' of post-war recession which underlie particular defects and surface phenomena (142). These causes are summarised unequivocally as the 'OVERBALANCE OF THE COMMERCIAL SPIRIT IN CONSEQUENCE OF THE ABSENCE OR WEAKNESS OF THE COUNTER-WEIGHTS' (169).

Sermon examines this dynamic conceptual relationship at length. There are three specific ideas within the argument that help to illuminate Coleridge's broader views on public and private duties. The first relates to his definition of the commercial spirit. This is initially defined in positive terms as embodying the 'industrious' part of the British 'national character', seen to have 'commenced ... with the institution of the Funds in the reign of William the Third' (Coleridge, 1972: 195). It is therefore coterminous with the national debt itself. Yet while the national debt (in its ideal form) is considered unifying and usuriously productive, the national character is subject to corruption through inadequate moral 'counterpoise' (189). In extreme form, this engenders the evaluation of human activity by its 'marketable value' via the 'specious names of utility' (189). Coleridge illustrates this point by forecasting the effects of the corrupted commercial spirit upon the traditional operations of agriculture. His vision is prophetic. Economies of scale determine that only large farms will attract 'extensive capital' (221). The coercive laws of competition determine that the farmer must 'prefer this system' for his 'own ease and security' (221), and must optimise productive output through automation. Social inequality is entrenched as increasing profits coexist 
alongside 'a peasantry sinking into pauperism' (212). These combined phenomena absolve the farmer - he feels - from moral engagement with the community: 'what as a Tradesman I cannot do, it cannot be my Duty, as a Tradesman, to attempt' (221). This vision of modern agriculture recognises, then, the connection between structural (public) economic phenomena and the private moral sense, insofar as the economy conditions the actions of the individual. However, the Tradesman's 'Duty' relates to their public role rather than their private and individual moral sense. For Coleridge, then, there remains the crucial duality between the moral duties of the individual in their public and private conduct.

The second idea in Sermon that informs Coleridge's conception of public and private indebtedness concerns the nature of the weakened counter-weights of the commercial spirit. These counter-weights fall into three categories. The first relates to our reflexive reverence for 'the ancient feeling of rank' (Coleridge, 1972: 170). The second is a sophisticated metaphysics that ruminates upon 'eternal truths' rather than 'the accidents of the senses' (120). Such accidents focus upon 'immediate profit or immediate pleasure', and are exemplified by the 'psychological Empiricism' of demagogic rhetoric, Humean arithmetic, and Paleyan ethics (170-3). The third counter-weight is provided by Anglicanism. This branch of Christianity is seen as undermined by the growth of Unitarianism and Quakerism, and their perceived failures to 'actuate the understandings of men' (200). The former creed is criticised for comprising 'a few plain doctrines' cherry-picked from scripture through the faculty of 'natural Common-Sense' (177-83), while the Quakers - despite their 'decorous morals' - are considered 'shrewd' in 'worldly concerns' (190). Putting to one side such derogatory views, the three counter-weights together place moral and theological ideas at the centre of Sermon's critique of commercial operations. I will return to these issues in the following section, when examining Coleridge's and Paley's reflections on the private debtorcreditor relationship.

The final idea informing Coleridge's examination of public and private indebtedness is the Kantian distinction between Things and Persons. This conceptual opposition is central to Coleridge's moral and political philosophy, and forms Sermon's most fruitful attempt to align the spheres of ethics and economics. For Coleridge (1972: 219-20), commerce is characterised by the fact that 'no distinction is ... acknowledged between Things and Persons'. Persons-as-labourers are objectified as 'Stock in Trade' exchangeable by the capitalist for monetary gain. Persons-as-consumers or debtors are objectified insofar as 'established character' becomes the currency of financial 'securities' (220). In contrast to commerce, the 'Aim of a State' in its 'ideal Mark' is to treat persons as persons. This requires the state's fulfilment of negative and positive duties. The key negative duty is 'the protection of person and property', while the key positive duty is to cultivate the 'faculties' of '[the] rational and moral Being' to foster the 'means of knowing their essential duties' (216-7). By enabling persons to develop the faculty of prudential understanding in this way, the state enables the individual moral agent to recognise - and perhaps resist - their treatment by commerce as things. I will return to these issues in the final section of the article, when considering Kant's engagement with the private debtor-creditor relationship.

Coleridge's examination of the national debt in 'Taxes' and Sermon thus offers a broadly coherent theory of public credit and taxation during the period of early-industrial capitalism. The essays also introduce the debt as a key symbol in his broader moral 
philosophy. They identify a range of linked ethico-economic oppositions that are embodied in and fostered by the debt, including the distinction between public and private axioms of indebtedness, the idea of the state and the material manifestations of the commercial spirit, the differences between persons and things, and the moral duties of the individual in their public and private conduct. These oppositions raise several questions that the essays leave unanswered. One question recalls the ethical distinction between usurious and abusurious debts: to what extent can the duties of the citizen towards the national debt be understood in terms of the debtor-creditor relationship? The answer to this question requires a consideration of how Coleridge responds to this relationship in his moral philosophy.

\section{III: Consequentialism and the debtor-creditor relationship}

Coleridge's economics anticipate recent studies on the ethics of indebtedness insofar as his assessment of public credit is shaped by the concepts of his moral philosophy. He therefore shares with modern scholars of debt an interest in the idea of the moral economy. This idea emerged during the eighteenth century in response to struggles over the encroachment of impersonal market forces upon the pricing structures of cooperative local trade. The supposed amorality of economic change was seen to be abetted by the emerging discipline of political economy, which was accused of removing ethical and theological considerations from the examination of economic phenomena (Götz, 2015: 149). However, such accusations downplayed the extent to which classical economics was developing its own ethical conception of human behaviour, rooted in what Adam Smith (1998: 23) calls our 'trucking disposition'. Developing this idea, later economists formulated the concept of the perfectlyrational utility-maximising agent (termed homo oeconomicus) in order to develop the normative and positive propositions of their social analysis. The concept remains contentious. One issue concerns the manner in which it embodies a duality within the field of normative ethics. On the one hand, homo oeconomicus exemplifies the utility-maximising calculations of the assumed agent of consequentialist egoism: a field of moral thought that primarily examines the outcomes of our actions. On the other hand, the role of homines oeconomici as a methodological presupposition of economic modelling is conceptually analogous to the synthetic a priori truths of Kantian deontology: a field of moral thought that examines the duties and obligations fostering actions (Hausman, 2008: 12). The concept consequently forms the locus of the relationship between public and private morality within modern economic theory.

Sermon's economic arguments offer a critique of the moral sense embodied in the idea of homo oeconomicus. This is chiefly conveyed through Coleridge's conception of the nature of the moral and theological counter-weights to the commercial spirit. However, these counter-weights are informed by a specific understanding of the private debtor-creditor relationship that is not outlined in the essay itself. To illuminate Coleridge's conception of this relationship requires a brief look at how his moral philosophy contrasts with Paley's consequentialist ethics. In Principles, Paley expounds a version of rule utilitarianism that promotes private moral axioms which, if universally adopted, would engender the greatest public wellbeing (Lockridge, 1977: 244). Coleridge's own moral philosophy is elucidated in several articles published in Friend that together propose 'principles of morality' formed 'in 
direct opposition to ... Paley' (1969, 1: 313-4). The articles censure Paley's system of ethics for assessing 'general consequences' as the 'best criterion of the right or wrong of particular actions' (314). Paley's system neglects the 'inward motives' of the will ('the essence of morality') by prioritising 'the outward act', and thereby 'changes the virtue commanded by the gospel into ... mere legality' (314). As we saw, it was on these grounds that Sermon criticised Quakerism, whose 'spirit of prudential motive' was seen to conflict with the 'spirit of obedience to the commands of Christ' (Coleridge, 1972: 186-7).

Coleridge's assessment of Paley's ethics can be summarised as a meditation on the differences between legal and moral conceptions of debt, duty, and obligation. Despite his contributions to the field of Christian apologetics, Paley's analysis of the debtor-creditor relationship in Principles is formulated in secular terms (for Coleridge, 'mere legality'). For example, Paley (1815: 114) concedes that the propositional nature of debt necessitates a repayment, claiming that 'Whoever borrows money is bound in conscience to repay it'. He defends this claim by evoking the societal impact of debtors refusing to settle their debts, arguing that 'whatever deprives the creditor of his power of coercion, deprives him of his security', a deprivation whose long-term impact is the erosion of the trust that enables the 'obtaining [of] credit [by] the poor' (116). Coercion in this context relates to secular law enforcing debt repayments wherever repayment is possible. However, Paley also recognises that certain debts may become unrepayable, and permits the law to impose 'a limited [enforcement] time to certain species of private securities' (93). The moral obligation to repay legal debts is therefore considered a social or 'relative' duty as contradistinguished from duties towards God (48). In this respect, Paley's consequentialist ethics permit secular law the scope to respond to the problem of abusurious debts.

Coleridge's own reflections on the debtor-creditor relationship occur in the context of his theological meditations. His critique of secular ethics is summarised in Friend, where he identifies the root of his own moral system as 'God ... the source of all obligation', and where God-created nature forms 'the aggregated material of duty' (Coleridge, 1969, 1: 112). However, Coleridge's most developed consideration of the relationship between debt and duty occurs in a passage from Reflection that ruminates on Christ's Redemption. The passage examines one of the 'principal Metaphors' used by St Paul to illustrate the consequences of the Redemption; namely, the '[satisfaction] of a Creditor's claims by a payment of the debt' (Coleridge, 1993: 320-1). Coleridge (326-7) summarises St Paul's idea of debt in the following terms:

Sin is, or involves an infinite Debt, (in the proper and law-court sense of the word, debt) - a debt owing by us to the vindictive Justice of God the Father, which can only be liquidated by the everlasting misery of Adam ... [The] Son of God ... resolved to pay the debt for us, and to satisfy the divine Justice by a perfect equivalent ... [The] agonies suffered by Christ were equal in amount to the sum total of the torments of all mankind ... hereafter.

Coleridge criticises the Pauline understanding of Redemption and the infinite debt for making the error of 'inferring the identity of the causes from a resemblance in the effects' (318). He illustrates the point by contrasting the concept of duty as related to financial and familial 
debts. If, Coleridge argues, an insolvent James owes Peter $£ 1,000$, and Matthew repays Peter $£ 1,000$ on James's behalf, then Matthew's money is a 'perfect equivalent' of James's duty to repay his financial debt (328). However, if an 'undutiful' James displays 'ingratitude' to his own mother, and Matthew steps in to perform the 'duties' of an 'affectionate Son' on James's behalf, then James's familial debt remains unpaid. If James later emulates Matthew's affectionate act towards his mother, then the effects in each case may well be 'similar' insofar as James becomes 'liberated' from indebtedness through the 'grace' of Matthew (329-31). But this resemblance of effects conceals the fact that James's familial debts and duties cannot be discharged by anyone but himself. Applying this analogy to the nature of Christian faith, Coleridge (1980-2001, 3: 47) terms this error " "the Debtor and Creditor Scheme" of Redemption', in which faith is misconceived as a plain balancing calculation between Christ's 'suffering' and the 'compassion in the ... Debtors Proxy, the Son' (26). As noted above, it was on these grounds that Sermon criticises Unitarianism, whose 'calculated' assessment of the 'effects' of the Resurrection are used to confirm the 'moral precepts' of scripture (Coleridge, 1972: 183).

The range of Coleridge's moral thought resists abridgment. Nonetheless, his analysis of the debtor-creditor relationship reveals one crucial idea that clarifies his conception of the national debt. This concerns the belief that Paley's neglect of inner motives in favour of outward acts 'confounds morality with law' (Coleridge, 1969, 1: 314). Deidre Coleman (1988: 156) identifies this idea as 'central' to Coleridge's political philosophy, and detects in Friend a wholesale adoption of Kant's distinction between morality and law as outlined in The Metaphysics of Morals (1797):

The mere conformity or non-conformity of an action with the law, without reference to the motive of the action, is called its legality (lawfulness). But that conformity in which the Idea of duty contained in the law is also the motive of the action is called its morality. (quoted in Coleman, 1988: 156)

Applying these categories to the issue of private financial debt, Coleridge (1969, 1: 94-5) contends that '[the] Law has rightly invested the Creditor with the power of ... imprisoning an insolvent Debtor' in cases where a debtor neglects their moral duty to settle their debt. However, a debtor's repayment of their debt in outward conformity to the law reveals nothing about the inner moral status of the act itself. Furthermore, if we take insolvency to refer to a debtor's inability (rather than mere refusal) to settle their debt, then the law may well imprison such debtors who nonetheless assent internally to the moral duty to repay debts. This scenario accords with Paley's view that such debtors should be legally penalised in order to maintain trust in the broader system of promises informing public credit and lending. However, it sits uneasily with the alignment in 'Taxes' between the citizen's private familial conduct and their public duty towards the national debt. To resolve this dilemma requires us to follow Coleridge into the internal world of deontological ethics.

\section{IV: Kantian deontology and the social contract}


Kant's moral philosophy examines the necessary obligations of the rational moral agent that derive from the ideas of duty. These obligations conform to the concept of the moral law that is outlined in three a priori categorical imperatives. Coleridge's reworking of Kantian deontology offers his most persuasive attempt to align the duties of private morality with those of public morality. Many critics argue that he never quite succeeds. For example, Timothy Michael (2015: 150) observes that the alignment of these two spheres is imperfectly resolved by Coleridge through an appeal to the 'morality-prudence distinction', relating respectively to the faculties of reason and understanding. As we saw, reason fosters the internal motives of private morality, while the understanding prudently marshals reason to inform the external acts of public expediency. For Michael (150), this 'rapprochement' between 'the individual' and 'the state' manifests most clearly in relation to the moral duties informing the concept of 'political obligation' and the idea of the social contract. It is for this reason that the social contract is conventionally seen to be 'the counterpart to the categorical imperative in political ethics' (Kersting, 1992: 355). Coleridge's conception of public and private debt is therefore clarified in relation to his development of these ideas.

Central to Kant's idea of the moral law is the ontological difference between persons and things. As we saw, this concept informs the duality between public and private debts examined in Sermon, but it also informs the opposition of financial and familial debts in Reflection. In this work, Coleridge (1993: 327) argues that 'morality commences with ... the sacred distinction between Thing and Person' on which 'all Law human and divine is grounded'. Unlike familial debts, financial debts are simply 'a question of Things' (329). This same idea underpins Sermon's critique of labour exploitation. Outlining his desire for the aristocracy to focus their energies upon the 'moral growth' of their tenants rather than the 'marketable produce' of their land, Coleridge seeks to justify the view in identical terms to those later used in Reflection:

On the distinction ... between Things and Persons, all law human and divine is grounded. It consists in this: that the former may be used, as mere means; but the latter dare not be employed as the means to an end without directly or indirectly sharing in that end. (1972: 218, 218n)

The passage paraphrases Kant's second formulation of the categorical imperative in Groundwork for the Metaphysics of Morals (Groundwork, 1785), known as the Formula of Humanity as End in Itself (FHE): 'Act so that you use humanity, as much in your own person as in the person of every other ... as end and never merely as means' (2002: 46-7). Sermon applies the imperative to argue that the spirit of trade engenders the use of persons as mere economic means to achieve the ends of financial profit. Whether this constitutes exploitation in moral terms rather than strictly economic terms hinges on the words 'mere' and 'merely' in each formulation of the imperative. As noted above, 'Taxes' argues approvingly that the national debt had made it 'impossible' for most of Britain's population to maintain their living standards 'without joining in the common industry' (Coleridge, 1969, 1: 233). If we put to one side issues relating to primitive accumulation suggested by the word 'impossible', then the passage in Sermon suggests that the shared ends of commercial growth engendered 
by the national debt are sufficient to pass the test of the second imperative. This moral claim ultimately underpins Coleridge's economic evaluation of the debt as usuriously productive.

The moral significances of debt and duty that Coleridge develops from Kant help us to reassess the two central claims that the poet makes concerning the national debt. The first claim relates to the idea of moral duty itself. In 'Taxes', Coleridge argues that the debt has 'added to our public duties' a 'feeling' akin to those of private familial 'necessity' $(1969,1$ : 234). The necessity of specific duties is tested by Kant in Groundwork to refine his formulations of the categorical imperative. For example, to test the Formula of Universal Law - which holds that the moral agent must 'act as if the maxim of your action were to become through your will a universal law of nature' (Kant, 2002: 38) - Kant offers two illustrations of perfect duties that conform to this moral law. The second illustration is the most important to the present article, and tests the imperative with reference to our perfect duty to keep our promises. ${ }^{3}$ The test draws upon the financial debtor-creditor relationship, and examines a scenario in which a debtor makes a false promise of solvency to receive a loan:

[the debtor's] maxim would be stated as follows: 'If I believe myself to be in pecuniary distress, then I will borrow money and promise to pay it back, although I know this will never happen'. Now this principle of self-love, or of what is expedient for oneself, might perhaps be united with my entire future welfare ... [but] "Is it right?" (Kant, 2002: 39)

Kant concludes that the maxim to obtain money through deception fails the test of the imperative and so constitutes an immoral act. However, this conclusion relates to the broader imperative to not make false promises, rather than to the specific obligations informing the financial debtor-creditor relationship. This difference is crucial. If we return to Coleridge's analogy of financial debt in Reflection (where James owes Peter £1,000), and we suppose that Peter knew before making the loan that James was incapable of repaying the money, does this alter James's duty to settle the debt? The dogmatic Kantian might argue that it makes no difference in respect to this specific imperative; James's non-repayment of his debt for whatever reason cannot become a universal law without harming the mutual trust in the promises that underpin all financial transactions (Douglas, 2015: 26).

For Coleridge, the situation is more complex. On the one hand, he recognises that prudential expediency necessitates the legal system to imprison individual debtors in order to maintain our shared public duties towards the financial system. On the other hand, he conceptualises interpersonal financial debts as principally constituting legal relations between things, not moral relations between persons. This opens the conceptual space in the sphere of private morality for Douglas's idea of abusurious debt. Extractive lending generates no duty for the debtor, because in such cases it is often the duty and not the debt that has been duplicitously engendered. Once again we see that the assertion in 'Taxes' concerning the necessary public duties towards the national debt rest on the presupposition that public debt is usuriously productive. This has remained a contentious issue since 1694.

The second central claim that Coleridge makes concerning the national debt relates to the idea of the social contract. In Sermon, Coleridge (1972: 157) argues that the operations of 
the debt can only be understood by those who contemplate 'the Ideal of a beneficent and judicious system of Finance'. The phrasing of the sentence echoes the description in Church of 'the idea of an ever-originating social contract' (1976: 15). The idea of the social contract recurs throughout Coleridge's mature political philosophy. However, he distinguishes the 'ever-originating' from the 'original' contract to explain what he considers the source of political obligation (1969, 1: 173-4). The idea of an original or foundational contract whether abstract or in the form of a historical and legal declaration of rights - is criticised on the basis that the 'sense of Duty' it impels in the citizenry 'must have pre-existed' to command their subsequent obligation (173). This sense of duty is therefore considered a moral rather than a legal imperative. In contrast, the idea of the 'ever-originating' contract has no abstract or historical point of inception. As a result, the contract is '[synonymous] with the sense of duty' that '[determines] our moral relations, as members of a body politic' (173$4)$. This liberates the sense of moral duty from any historically-specific body politic or set of legal obligations, and aligns it with the Kantian idea of universal moral duty. ${ }^{4}$ Bringing these ideas together, I contend that the sense of duty referred to here is identical to the moral sense that Coleridge saw in Sermon as threatened by the overbalance of the commercial spirit in Britain's post-Waterloo economy. The public duty seen in 'Taxes' as fostered by the national debt is an essential component of this moral sense, and consequently aligns Coleridge's economic conception of the national debt with his moral idea of the social contract.

The correspondence between the ideas of the debt and the social contract is rooted, then, in the moral duties of the individual citizen. This argument is supported by the manner in which Coleridge's reflections on the idea of the 'ever-originating' social contact are frequently aligned with Kantian imperatives. For example, he asserts that 'the idea ... evolved out of the yet higher idea of person, in contra-distinction from thing', and that the 'Idea ... [exists] efficaciously in the Moral Being of every free Citizen' (Coleridge, 1976: 15; 1980-2001, 2: 1148). The former claim cites the duality between persons and things that inform Kant's second categorical imperative (FHE), and which underpins the economic arguments in Sermon. The latter claim affirms the rational autonomy of the free individual that informs Kant's third and final formulation of the categorical imperative, the Formula of Autonomy: 'the idea of the will of every rational being as a universally legislative will' (2002: 50). Although Coleridge does not explicitly cite Kant's third imperative in his analysis of the national debt, he seems to assume that the duties fostered by the debt are those of the autonomous individual. This assumption forms the most difficult challenge to aligning his economic and ethical thought. For example, the assertion that public credit should foster private moral duty in the citizen is underpinned by a legal obligation to incur the debt of taxation, and, as noted above, of the early-nineteenth century labouring class to have entered into wage relations. The citizen may outwardly conform to these often-legal obligations, but this remains distinct from an internal moral conformity to the corresponding ideas of duty that Coleridge wishes to encourage in his economic writings.

In summary, the British national debt appears in Coleridge's economic thought as the closest form of the idea of the social contract. In certain respects, the debt is 'everoriginating' insofar as it is seen to ever-perpetuate both productive investment in the nation's infrastructure and deference towards hierarchical relations of production, but also to foster the moral faculties and freedoms of the individual. The consequent duty of the indebted 
citizen towards the financial system is echoed and reinforced in Coleridge's understanding of the infinite debt of Anglican faith. However, for the true believer, indebtedness constitutes a relationship between persons and not between things, and therefore offers scope to distinguish legal debt from moral duty in the sphere of financial relations. As a result, the national debt might instead be interpreted as closer in spirit to the idea of an originated social contract with an identifiable origin. Sermon dates the emergence of the commercial spirit with the material foundation of the debt in 1694. The necessity of successive generations to service the debt constitutes a form of indebtedness no amount of prudential expediency on the part of the state or the individual can eradicate without restructuring. If conceived in terms of historically-contingent, abusurious wealth extraction, then, the debt offers the grounds upon which the radical empiric may - Coleridge fears - transform our comprehension of the moral significances of debt, duty, and obligation, and consequently destabilise social and economic hierarchy. For many this remains a vital political project.

\section{Conclusion}

Coleridge anticipates recent scholarship on the ethics of indebtedness by examining public debt through the lens of moral philosophy. His work enables us to identify and question the significance of ethical ideas in economic thought. This conceptual relationship has played an increasingly important role in the aftermath of the global financial crisis of 2007-2008. For example, the resultant policy responses to debt overhang and structural deficits are frequently justified through unexamined moral concepts. A recurring instance is the idea of 'fairness'. Two centuries after Coleridge published 'Taxes', the United Kingdom's coalition government defended the 'Fairness' of its austerity programme in an HM Treasury Budget (2011: 4), asserting that '[tackling] the deficit will ensure that future generations are not burdened with unsustainable debt'. Such political claims are not restricted to openly partisan institutions. The International Monetary Fund (2015: 25) cites 'concerns about fairness' in relation to the competing claims of financial instruments. Such claims impacted the recent restructuring programmes that aimed to stabilise the sovereign debt crises of Greece and Cyprus. The economic ideas informing these programmes are complex and contested, and few would argue that Coleridge's economics match their sophistication. Nonetheless, such appeals to 'fairness' reveal the centrality of ethics in their responses to the issue of debt. It is chiefly for this reason that the conceptual precision of Coleridge's moral thought enables us to interrogate their arguments. The ideas and dualities in his work help us to question whether cuts to key public services constitutes the unethical treatment of vulnerable persons as things, whether corresponding tax increases engender a moral duty in the private citizen's legal obligation to pay, and whether the treatment of elected governments as profligate debtors by international financial institutions confounds axioms of public and private duty and obligation. As we have seen, Coleridge examines such issues in relation to his understanding of Britain's national debt in the early-nineteenth century. However, the continued relevance of his economic thought lies in its capacity to prompt us to assess the ethics informing present economic programmes.

\section{References}


Calleo, David P. (1966). Coleridge and the Idea of the Modern State. New Haven: Yale UP. Coleman, Deirdre (1988). Coleridge and The Friend (1809-1810). Oxford: Clarendon Press. Coleridge, Samuel Taylor (1969). The Collected Works of Samuel Taylor Coleridge. Volume 4: The Friend. Ed. Barbara E. Rooke. 2 vols. London: Routledge \& Kegan Paul; Princeton: Princeton UP.

Coleridge, Samuel Taylor (1972). The Collected Works of Samuel Taylor Coleridge. Volume 6: Lay Sermons. Ed. R. J. White. London: Routledge \& Kegan Paul; Princeton: Princeton UP.

Coleridge, Samuel Taylor (1976). The Collected Works of Samuel Taylor Coleridge. Volume 10: On the Constitution of the Church and State. Ed. John Colmer. London: Routledge \& Kegan Paul; Princeton: Princeton UP.

Coleridge, Samuel Taylor (1980-2001). The Collected Works of Samuel Taylor Coleridge. Volume 12: Marginalia. Eds. George Whalley and H. J. Jackson. 6 vols. London: Routledge \& Kegan Paul; Princeton: Princeton UP.

Coleridge, Samuel Taylor (1990). The Collected Works of Samuel Taylor Coleridge. Volume 14: Table Talk. Ed. Carl Woodring. 2 vols. London: Routledge \& Kegan Paul; Princeton: Princeton UP.

Coleridge, Samuel Taylor (1993). The Collected Works of Samuel Taylor Coleridge. Volume 9: Aids to Reflection. Ed. John Beer. London: Routledge \& Kegan Paul; Princeton: Princeton UP.

Colmer, John (1959). Coleridge: Critic of Society. Oxford: Clarendon Press.

Connell, Philip (2001). Romanticism, Economics and the Question of 'Culture.' Oxford: Oxford UP.

Dick, Alexander (2013). Romanticism and the Gold Standard: Money, Literature, and Economic Debate in Britain 1790-1830. Basingstoke: Palgrave Macmillan.

Dome, Takuo (2004). The Political Economy of Public Finance in Britain, 1767-1873. London; New York: Routledge.

Douglas, Alexander X. (2015). The Philosophy of Debt. London: Routledge.

Edwards, Pamela (2004). The Statesman's Science: History, Nature, and Law in the Political Thought of Samuel Taylor Coleridge. New York: Columbia UP.

Götz, Norbert (2015). “"Moral Economy”: Its Conceptual History and Analytical Prospects.' Journal of Global Ethics 11:2, 147-162.

Graeber, David (2011). Debt: The First 5,000 Years. New York: Melville House.

Hausman, Daniel M. (2008). The Philosophy of Economics: An Anthology. $3^{\text {rd }}$ ed. New York; Cambridge: Cambridge UP.

HM Treasury (2011). Budget 2011. HC836. London: The Stationery Office. <https://www.gov.uk/government/uploads/system/uploads/attachment_data/file/2474 83/0836.pdf >, last accessed 3 December 2016.

Hume, David (2008). Selected Essays. Ed. Stephen Copley. Oxford: Oxford UP.

IMF (2015). 'The Fund's Lending Framework and Sovereign Debt - Further Considerations - Annexes'. Policy Paper 10-11. <http://www.imf.org/external/np/pp/eng/2015/040915.pdf>, last accessed 3 December 2016. 
Kant, Immanuel (2002). Groundwork for the Metaphysics of Morals. Ed. and trans. Allen W. Wood. New Haven; London: Yale UP.

Kennedy, William F. (1958). Humanist versus Economist: The Economic Thought of Samuel Taylor Coleridge. Berkeley: California UP.

Kersting, Wolfgang (1992). 'Politics, Freedom, and Order.' The Cambridge Companion to Kant. Ed. Paul Guyer. Cambridge: Cambridge UP. 342-366.

Lazzarato, Maurizio (2012). The Making of the Indebted Man: An Essay on the Neoliberal Condition. Trans. Joshua David Jordan. Los Angeles: Semiotext(e).

Lockridge, Laurence S. (1977). Coleridge the Moralist. Ithaca: Cornell UP.

Marx, Karl (1992). Early Writings. Trans. Rodney Livingstone and Gregor Benton. London: Penguin in Association with New Left Review.

Michael, Timothy (2015). British Romanticism and the Critique of Political Reason.

Baltimore, MD: Johns Hopkins UP.

Mill, John Stuart (1985). 'Coleridge.' The Collected Works of John Stuart Mill. Volume X:

Essays on Ethics, Religion, and Society. Ed. John M. Robson. Toronto: Toronto UP;

London: Routledge \& Kegan Paul.

Mitchell, Brian R. (1988). British Historical Statistics. Cambridge: Cambridge UP.

Morrow, John (1990). Coleridge's Political Thought: Property, Morality, and the Limits of

Traditional Discourse. Basingstoke: Macmillan.

Onions, C. T., ed. (1978). The Oxford Dictionary of English Etymology. Oxford: Clarendon Press.

Paine, Thomas (2008). Rights of Man, Common Sense, and Other Political Writings. Ed.

Mark Philp. Oxford: Oxford UP.

Paley, William (1815). The Principles of Moral and Political Philosophy. Boston: West and Richardson.

Perry, Seamus (1999). Coleridge and the Uses of Division. Oxford: Clarendon Press.

Smith, Adam (1998). An Inquiry into the Nature and Causes of the Wealth of Nations: A

Selected Edition. Ed. Kathryn Sutherland. Oxford: Oxford UP.

Taylor, Henry (1888). Correspondence of Henry Taylor. Ed. Edward Dowden. London:

Longmans, Green, and Co.

Winch, Donald (1996). 'The Political Economy of Public Finance in the 'Long' Eighteenth Century'. <http://arts.st-

andrews.ac.uk/intellectualhistory/islandora/object/intellectual-

history\%3A56/datastream/OBJ/view>, last accessed 16 October 2016.

\footnotetext{
${ }^{1}$ Onions (1978: 247-8) records that the English word 'debt' takes on its present meaning of 'owe' during the thirteenth century. This develops the root (Latin, dēbitum; 'what is owed') by shifting signification from the thing owed to the state of owing, and therefore establishing the person of the 'debtor' as 'one who owes'. 'Duty' emerges at the same time to signify both 'conduct due towards a superior' and 'obligation' (Old French, due), with a simultaneous financial inflection denoting 'due charge', and later in the fifteenth century to denote 'payment enforced or levied' (296). 'Obligation' emerges to signify 'bind by oath' (Latin. obligāre), and during the sixteenth century to denote 'make indebted' and 'constrain' (620).
} 
${ }^{2}$ For detailed examinations of Coleridge's political epistemology, see John Morrow (1990: 73-99) and Timothy Michael (2015: 129-155). Michael (129) analyses 'the necessary connection' in the poet's work 'between how the mind functions ... and the validity of particular political arrangements'.

${ }^{3}$ Kant's first illustration clarifies the perfect duty we hold to ourselves to refrain from suicide. He argues that the 'principle of self-love' prompting suicide creates an untenable contradiction within the law of nature between the destruction and the 'furtherance of life' (2002: 38).

${ }^{4}$ Pamela Edwards (2004: 145-6) argues that one of Coleridge's developments of the Kantian Idea was the manner in which he accords Ideas a 'constitutive reality' rather than a merely 'regulative role', allowing it an efficacy to '[form and shape] the material world of phenomena'. 